$$
\text { 閉鎖孔ヘルニアの } 6 \text { 例 }
$$

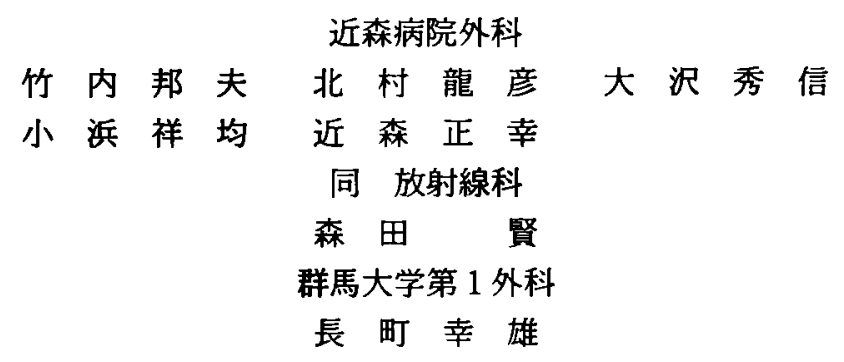

閉鎖孔ヘルニアは，比較的稀な疾思で，高齢で瘦せた女性に多く，術前の確定診断率 は低い. 今回われわれは, 過去 9 年間に 6 例の閉鎖孔へルニアを経験し，その内の 4 例 に緊急 CT を施行し確定診断し得た。年齢は73歳から93歳までで, 平均84.3歳. 性別は すへて性であった．Howship-Romberg sign は 3 例（50\%）に陽性．嵌頓部位は左右 各々 3 例ずつであった。 4 例に緊急 CT を施行し, 全例恥骨結節レベルのスライスで, 恥骨筋と外閉鎖筋の間に腫瘁陰影を認め, 閉鎖孔へルニアの嵌頓と確定猃断し得た。 6 例全例に根治手術を施行し救命し得た。閉鎖孔へルニアの診断は, 以前は困難で治療も 遅れがちであったが，近年 CTによる確定診断例の報告が増加している．原因不明の高 龄なイレウス患者に対し本症を疑った場合には，CT 検査はその確定診断に極めて有用 である。

柬引用語：閉鎖孔へルニア，CT

\section{緒言}

閉鎖孔へルニアは此較的稀な疾患で，高齢の女性に 多い. 以前は, 術前の確定診断が困難であったが, 1983 年 Meziane ら"が初めて閉鎖孔ヘルニアに対するCT の有用性を報告して以来，CTによる確定診断の報告 が散見されるようになった．今回われわれは，過去 9 年間に 6 例の閉鎖孔へルニアを経験し，そのうち 4 例 に緊急 CTを施行して確定診断し得たので報告する.

\section{症例の内訳}

1985年 7 月〜1993年 7 月の 9 年間に当科で経験した 閉鎖孔へルニアは 6 例である (表 1 ). 年齢は73〜93歳, 70 歳代 2 例，80歳代 2 例，90歳代 2 例で，平均年齢は 84.3歳と高齢であった。性別は，6例共すへてて女性で あった．閉鎖神経の圧迫症状である HowshipRomberg signは，3例 (50\%)に陽性であった。へル ニアの嵌頓部位は，左側右側共に 3 例であった。

1994年 9 月13日受付 1995年 2 月16日採用

\section{CT 像}

緊急 CT 4 例に施行した. 全例, 恥骨結節レベル のスライスで，恥骨筋と内閉銷筋，恥骨筋と外閉鎖筋 の間に腸管による腫瘤陰影を認め, 閉鎖孔へルニアの 嵌頓と確定診断し得た。図 1 は, 緊急 CT 像である. 右恥骨筋と右外閉鎖筋の間に卵円形の脱出腸管と思わ れる low density mass を認める。

手術方法ととの所見

6 例全例に手術を施行した．嵌頓内容はすべて回腸 であった。腸管穿孔 2 例 (33\%), 腸管切除を要したも の 4 例 $(67 \%)$ であった. ヘルニア塞の処置に関して

表 16 症例の内訳

\begin{tabular}{|c|c|c|c|}
\hline 年 & 路 & 73葴～93歳 & 平均 84.3 侗 \\
\hline 性 & 別 & 女性 6 例 & 男性なし \\
\hline \multicolumn{2}{|c|}{$\begin{array}{l}\text { Howship. } \\
\text { Romberg sign }\end{array}$} & \multicolumn{2}{|c|}{ 陽性 3 例 $\left(50^{\circ} \%\right)$} \\
\hline \multicolumn{2}{|c|}{ 嵌頓部位 } & 左側 3 例 & 右側 3 例 \\
\hline
\end{tabular}




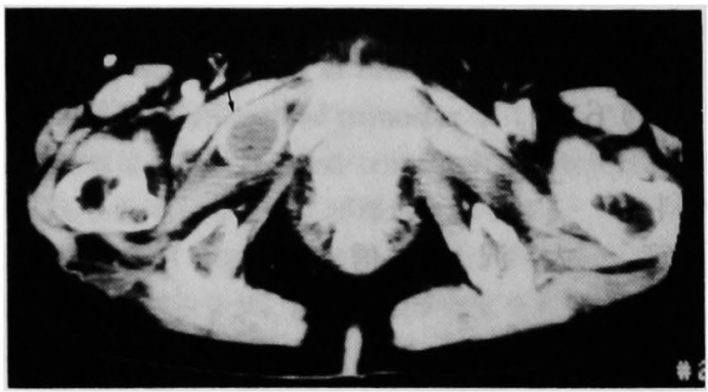

図 1 閉鎖孔へルニア嵌頓症例（86歳，女性）におけ る叕急腹部造影 X 線 CT

表 2 手術の所見及び方法

\begin{tabular}{|c|c|}
\hline 腸管穿孔 & 2例 (33\%) \\
\hline 腸 & 4 例 $(67 \%)$ \\
\hline ヘルニア貫処理 & 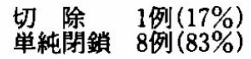 \\
\hline
\end{tabular}

は，切除例は 1 例（17\%）で，他の 5 例（83\%）は単 純閉鎖のみを施行した（表 2 ）。

症例

緊急 CTが有用であった症例を紹介する。

患者：73歳，女性.

主訴：全身倦怠感, 腹痛.

既往歴：胃潰瘍.

家族歴：特記すべきことなし。

現病歴：1993年 7 月14日, 全身僚急感と腹痛が出現 したが自宅にて様子をみていた。7月16日, 腹痛の増 強を訴え，当院内科を受診す。

入院時現症：身長 $145 \mathrm{~cm}$, 体重 $36 \mathrm{~kg}$. 眼瞼結膜に軽 度の負血を認める。眼球結膜に黄㾝はない. 胸部に異 常を認めず．腹部は下腹部を中心に膨隆し非限局性の 圧痛を認めるが，筋性防御は認めない.

入院時検査成績: WBC $10,300 / \mathrm{mm}^{3}$ と上昇. $\mathrm{RBC}$ $412 \times 10^{4} / \mathrm{mm}^{3}$, Hb $9.7 \mathrm{~g} / \mathrm{dl}, \mathrm{Ht} 29.5 \%$ と低色素性小 球性貧血を認めた。また BUN $98.8 \mathrm{ng} / \mathrm{dl}, \mathrm{Cr} 2.4 \mathrm{ng} /$ dl で, 脱水と腎機能障害を認めた. LDH は683IU/L と 高値を示した。

腹部単純 $\mathbf{X}$ 線写真 (図 2 )：小腸ガスを多量に認め, イレウス状態であった。

CT 所見（図 3）：7月16日に施行した緊急骨盤造影 CTでは, 恥骨結節レベルのスライスで, 左外閉鎖筋と 左恥骨筋の間に，辺緑が高吸収域で，内部が低吸収域 の円形腫瘤を認め，腸管が脱出した左閉鎖孔ヘルニア

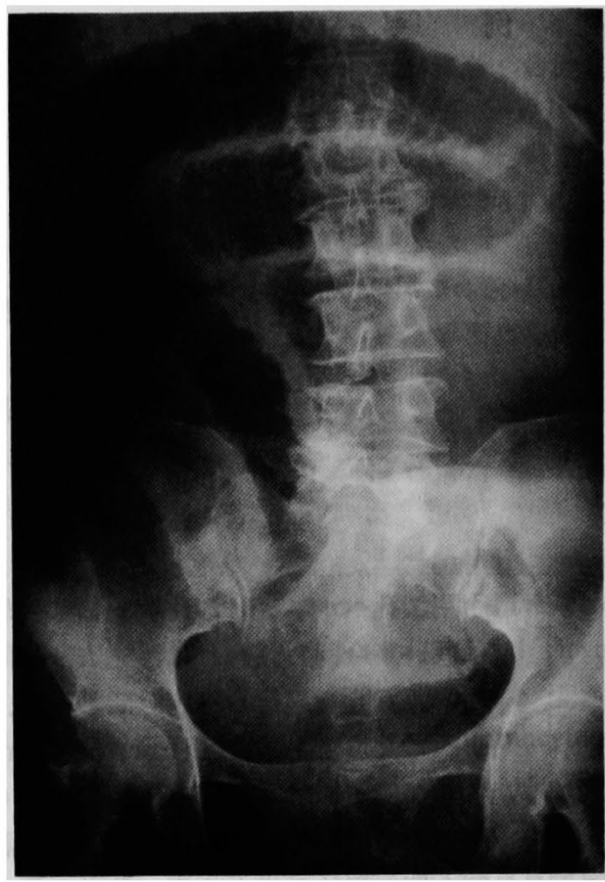

图 2 臥位腹部単純 $\mathbf{X}$ 線写萝 症例: 73歳, 女性

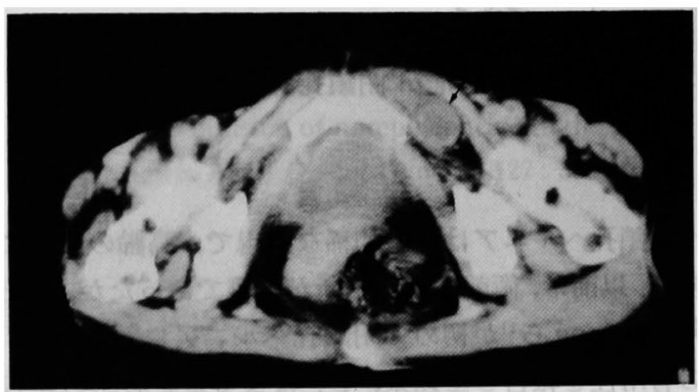

図 3 腹部 X 線造影 CT 症例：73歳, 女性

の嵌頓と診断した。

手術所見（図 4): 脱水症状等の改善後，7月17日, 全身麻酔下に手術を施行した。 下腹部正中切開にて開 腹. 少量の黄色透明な腹水を認め, 回腸末端より約 $1 \mathrm{~m}$ 口側の回腸壁の一部が左閉鎖孔に嵌頓した Richter 型 ヘルニアで,これより口側の小腸は著明に拡張してい た.また小腸ループが右側で, 盲腸が左側にあるタイ プの腸回転異常症を合併していた，嵌頓を解除し，強 い循環障害に陥った絞扼部を含め約 $10 \mathrm{~cm}$ の腸管切除 を行った. ヘルニア豪は切除した。 


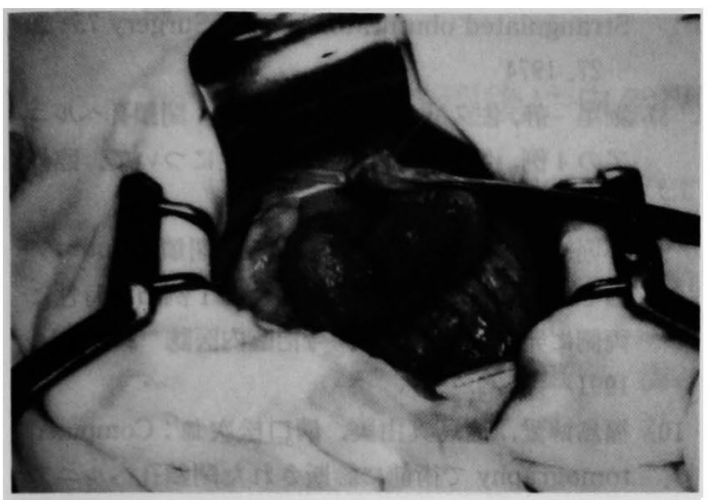

図4同一症例の手術所見

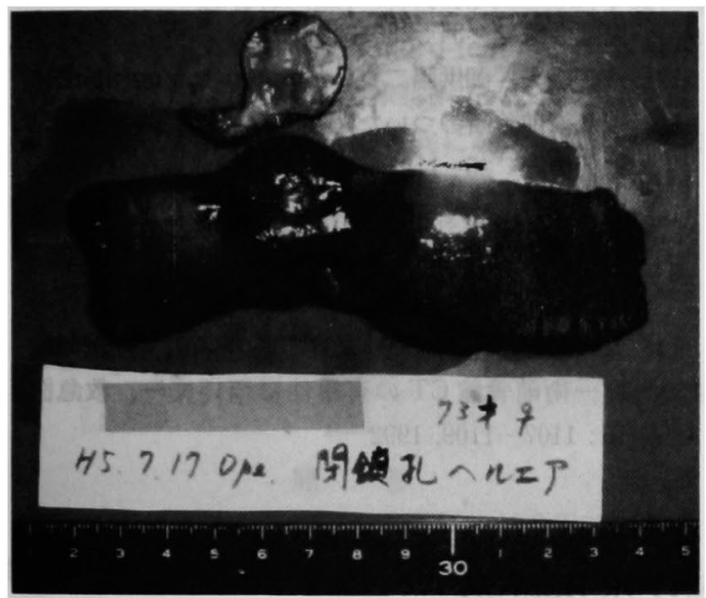

図 5 同一症例の切除標本

切除標本（図 5 ）：回腸壁の一部が嵌頓し，壊死に 陷っていた。

術後経過：術後経過は良好て, 術後第20病日に退院 となった.

\section{考 察}

閉鎖孔ヘルニアは閉鎖動・静脈, 神経などが通過す る閉鎖管の入口部をへルニア門とするへルニアであ ク，ほとんどが腹痛，嘔吐などのイレウス症状にて訪 医し，確定診断のつかないまま開腹手術を受け，初め て本症と診断されることが多い。本邦で1926年に川 瀬”が初めて報告して以来, 1988年に森村ら ${ }^{31}$ が246例, 1991年に梅田ら゙が270例を集計した結果を報告して

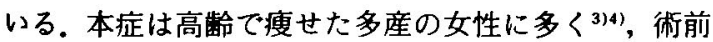
診断率は報告によりまちまちであるが20〜30\%であ

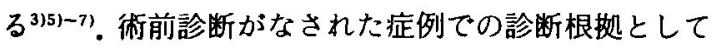
は Howship-Romberg 徵候の存在が最も多く, 次いで
小腸造影, 腹部単純 X 線写真の順になっている゙. Howship-Romberg 徵候, 腹部単純 X 線写真の診断 は, 確診というょり疑診であり，小腸造影は手技的に やや煩雑である.しかしこれらの症例は稀であり，よ り簡単で客観性のある検査が望まれる.1983年 Meziane ら"が初めて閉鎖孔へルニアに対するCT の

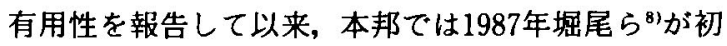
めて CT 検査により術前診断のついた症例の手術結果 を報告し，それ以後閉鎖孔へルニアにおける CT 診断 の報告例が増加し, その有効性も確立されてき $た^{91 \sim 13\}}$.

閉銷孔は, 恥骨と坐骨によって囲まれた骨の間隙で， 内外閉鎖筋と閉鎖膜によって閉じられており，その上 前方部に閉鎖動・静脈, 神経が通る閉鎖管が存在し, この部にヘルニア門が形成されている. CTでは恥骨 結節レベルのスライスで撮影すると，恥骨結節，大転 子あるいは坐骨粗面を付着部とした恥骨筋, 内外閉鎖 筋の同定が可能で, 腹側より恥骨筋, 外閉鎖筋, 内閉 鎖筋の順である”。通常は筋層間に腫瘤は存在しない が, 本症の場合, この筋層間に脱出した腸管が低濃度

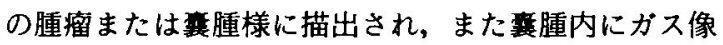
が存在することもある. 特に造影 CT では, 腫瘤辺縁 がエンハンスされる．また腹腔内の腸管との連続性を 証明できる場合もある ${ }^{812) 141}$. 自験例では 6 例中 4 例に 骨盤造影 CT を施行し， 4 例共恥骨筋と閉鎖筋の間に 辺縁がエンハンスされた低濃度腫瘤が存在し，閉鎖孔 ヘルニアの嵌頓と確定診断し得た。 CT 検査は非侵襲 性でしかも簡単であり, 客観性, 普遍性に富み, 閉鎖 孔へルニアの診断に極めて有用であると思われる。

本症の治療は, 診断がつき次第, 手術を行うべきで ある. 手術方法には, 開腹法と鼠径部からの腹膜外到 達法があるが, 腸管塄死の存在の有無の見極めが可能 であること，腹膜炎にも对処できること，対側の閉鎖 孔も観察できることなどの諸点から，正中切開による 開腹法が最も安全で確実である．自験例もすべて正中 切開による開腹法によるアプローチを行った。へルニ ア門に関しては何らかの方法で閉鎖する処置が必要で ある．自験例では 5 例に壁側腹膜の結節縫合， I 例に ヘルニア赛の結紮切除を行ったが，いずれの症例にも 術後の再発は認められていない。

\section{結 語}

過去 9 年間に 6 例の閉鎖孔ヘルニアを経験し以下の 結論を得た。

1. 73歳から93歳までの女性で, 平均84.3 4 4.7歳で 
あった。

2. 腸管穿孔は 2 例 $(33 \%)$ ，腸管切除を要したもの は 4 例 (67\%) であった。

3. 緊急 CTを行った 4 例全例共, 術前確定診断がで き,閉鎤孔へルニアの診断に緊急 CT は極めて有用で あった。

\section{文 献}

1) Meziane MA, Fishman EK, Siegelman SS: Computed tomographic diagnosis of obuturator hernia. Gastrointest Radiol 8: 375-377, 1983

2）川瀨 潔：閉鎖孔へルニアの1例. 日外会誌 27 : $1839-1840,1926$

3）森村尚登, 西山潔, 渡会伸治他：手術前に診断て きた閉鎖孔へルニアの1例並びに本邦報告246例 の文献的考察. 日臨外医会誌 $49: 132-138,1988$

4）梅田潤一郎, 三重野寛治, 三浦誠司他：閉鎖孔へル ニアの 2 例及び本邦報告例の文献的考察. 帝京医 誌 14:491-496, 1991

5）佐々木誠, 林 訑欽, 草野義輝他：閉鎖孔ヘルニア の1例及び本邦報告例の文献的考察。広島医 39 ： 1233-1236, 1986

6）紙田俉彦, 山口善友, 徳田 均他：閉鎖孔ヘルニア の 4 例一特に早期晾断について. 外科診療 20 ： 374-377. 1978

7) Gray SW, Skandalakis JR. Soria RE, et al:
Strangulated obuturator hernia. Surgery $75: 20$ $-27,1974$

8）堀尾 静, 佐久間温巳, 松崎正明他：閉鎖孔へルニ アの 4 例, 特に術前 CT の有用性について. 臨外 $42: 661-664,1987$

9）小堀迪夫, 徳永常発, 岡本満夫他：閉鎖孔へルニア の 2 症例一CTにより描出された 1 例と異時性に 両側に発生した 1 例一. 今治臨内医誌 $2: 6-14$, 1991

10）福島博愛, 福島真由美, 清口松次他: Computed tomography で術前に診断された閉銷孔へルニア の1例. 臨と研 $68: 1747-1748,1991$

11）顔 克明, 吉田 淳, 佐野 警他：術前診断にCT が有効であった閉銷孔へルニアの 1 治験例。兵庫 医師会医誌 $34: 23-26,1991$

12）齐藤盛夫, 御供陽二 : Computed tomography に より術前診断のついた閉銷孔ヘルニアの1例，日 消外会誌 25: 1127-1130, 1992

13）高木洋行, 上沢 修, 小林正典：CTにより術前訩 断のついた閉鎖孔へルニアの1例. 日消外会読 25 : 1127-1130, 1992

14）若月俊郎，山本敏雄：閉鎖孔ヘルニア 4 症例の検 討一術前骨盤 CT の有用性について一. 救急医 16 : 1107-1109, 1992

\title{
SIX CASES OF OBTURATOR HERNIA
}

\author{
Kunio TAKEUCHI, Tatsuhiko KITAMURA, Hidenobu OOSAWA, Yoshihito KOHAMA, \\ Masayuki CHIKAMORI and Ken MORITA \\ Department of Surgery and Radiology, Chikamori Hospital \\ Yukio NAGAMACHI \\ First Department of Surgery, Gunma University School of Medicine
}

Obturator hernia is comparatively rare, and often occurs in older and lean females. The preoperative diagnostic rate is low. We have experienced 6 cases of obturator hernia in a last 9 year period. In 4 cases of them emergent computed tomography (CT) was enforced, and the correct diagnosis was obtained in all of them. There was a mass shadow between the pubic muscle and obturator muscle in the level of pubic nodule. Radical operation was performed for all the 6 cases and their liver were successfully saved. Formerly the diagnosis of the obuturator hernia was difficult and the delayed treatment tended to occur, but recently, correctly diagnosed cases by CT have been increasingly reported. When the disease is suspected in a aged patient with intestinal obstruction of unknown origin, simple, non-invasive and objective CT is extremely useful to make the deinite diagnosis. 